\title{
Editorial
}

\section{T. Voit Pediatric Neurology on the Threshold of a New Millenium}

When the German physician Christoph Wilhelm Hufeland, in 1793, published the 2nd edition of his book "Bemerkungen über die natürlichen und geimpften Blattern zu Weimar im Jahre $1788^{\prime \prime}$ (Annotations on the natural and inocculated smallpox in Weimar in 1788) he added an appendix, some 390 pages long, on different diseases of childhood because he felt it might be useful to circulate some practical ideas regarding the wellbeing of children. The large volume of these annotations as well as similar undertakings by Schäffer and Armstrong, to name only two, clearly indicated that the time was ripe for what was then a new subspecialty, pediatrics, at the beginning of the 19th century. The latter not only saw this subspecialty emerge and grow with the first Chair of Pediatrics created in April 1845 at the Royal Karolinska Medico-Surgical lnstitute in Stockholm but also experienced the struggle for independence of other fields such as neurology. Further stratification into more subspecialties followed soon.

Pediatric Neurology, with half a century to its credit and roots going back into the 19 th century, is still a relatively young discipline. If we turn from the recent past to the future, are we to expect less changes or that the speed of new developments slows down? Hardly. It is in fact quite predictable that this field will become subdivided into multiple subdisciplines, e.g. epileptology, neurogenetics, myology, etc. The question for the time being is more if the resulting scenario will lead to fragmentation like bits and pieces breaking off from an iceberg or if the resulting diversity in turn stimulates the growth of each of its parts as in a thriving organism. The clinical setting with one patient affected by (in the majority of cases) one disorder favours a holistic approach but clearly increased understanding for processes like pathophysiological mechanisms, environmental influences and modifying genes are strong centripetal forces, and the more we understand the more of these is to come.

Much of the development we will see will depend not only on external influences like the future of science or developing media but also, and especially, on the key players in the field and their attitude. Certainly the need for information and integration of new data into evolving concepts of disease or research remains a challenge. I am convinced that for the century ahead of us, and let us take that short-sighted view on the brink of a new millennium, there will be an increasing need for the well informed clinician-scientist in pediatric neurology, the person who can integrate and amalgamate the exploding flux of news and blend it into a sensible approach for the benefit of his patients. This is not an easy task, and Neuropediatrics will try to assist in promoting this goal by offering exciting news, a forum for critical discussions, and continuing education in both clinical and basic science aspects of pediatric neurology. The Editorial Board is deeply grateful to the many colleagues around the world without whose help, support, and expertise this task could not be mastered, and who supported the journal by providing reviews and expert council. Their names are listed below.

In adapting to the challenges ahead of us Neuropediatrics will be edited, from January 2000, by Georg Thieme Publishers. The journal will change a little in layout, and will also become available online via www. This will make it even more accessible for its readership and hopefully further stimulate the crosstalk between those who wish to take an active role in this exciting field of science and of clinical medicine.

Thomas Voit, Executive Editor

T. Abe - N. L. Antunes - K. Aso - M. Beck - L. E. Becker

F. Berthet - B. Bourgeois - O. Braddick - G. Cioni

F. Cowan - M. P. DiFazio - S. DiMauro - N. Dodge

G. Enders - N. Forsting - J. Frahm - Y. Futagi

A. Gabrëels-Festen - J. Gärtner - G. Gillessen-Kaesbach

J. Golden - G. Greisen - P. Guichenai - B. Hagberg

F. Heinen - R. Hohlfeld • G. L. Holmes - Y. Inoue

H. Iwamoto - J. Jaeken - W. Kaufmann - H. Kimura

J. Kohyama - R. Korinthenberg • H. Kramer

W. Kreth - W. Krivit - W. Logan • B. Lorenz

H. Lou - J. J. Martin - Y. Matshushima - A. Munnich

S. Naidu - W. Neubauer - H. Oguni - E. Oka - M. Osawa

C. P. Panayiotopoulos - T. Partridge - V. Raemaekers

I. Rapin - A. Reis - M. Rivkin - C. Roll - T. Rosenbaum

E. Ross - J. Rotteveel - J. M. Schröder - R. Seitz

J. Soul • O. Steinlein - U. Stephani - J. Tanaka

G. Taylor - F. Tomé - N. Topçu - I. Tuxhorn

B. Urlesberger - V. Wahn - G. Wenk - E. Wilichowski

J. E. Wraith - A. Wynshaw-Boris 